MATEC Web of Conferences 9, 02005 (2013)

DOI: $10.1051 /$ matecconf/20130902005

(C) Owned by the authors, published by EDP Sciences, 2013

\title{
Fire hazards of exterior wall assemblies containing combustible components
}

\author{
Nathan White ${ }^{1}$, Michael Delichatsios ${ }^{2}$, Marty Ahrens ${ }^{3}$ and Amanda Kimball ${ }^{4}$ \\ ${ }^{1}$ Commonwealth Scientific and Industrial Research Organisation, Melbourne, Australia \\ 2 University of Ulster, Jordanstown, Northern Ireland \\ ${ }^{3}$ National Fire Protection Association (NFPA), Quincy, MA \\ ${ }^{4}$ Fire Protection Research Foundation, Quincy, USA
}

\begin{abstract}
The Fire Protection Research Foundation has funded a research project on "fire hazards of exterior wall assemblies containing combustible composites". This paper presents preliminary findings from the project. In particular, statistics relating to exterior wall fires have been reviewed. Exterior wall fires appear to account for somewhere between $1.3 \%$ and $3 \%$ of structure fires in the selected property types investigated. Fires involving combustible exterior wall assemblies are low frequency events however the resulting consequences in terms of extent of fire spread and injuries and fatalities can be large as demonstrated by selected fire incident case studies. An overview of this project and it's further work is provided.
\end{abstract}

\section{INTRODUCTION}

Many combustible materials are used today in commercial wall assemblies to improve energy performance, reduce water and air infiltration, and allow for aesthetic design flexibility. There have been a number of documented fire incidents involving combustible exterior walls but a better understanding is needed of the specific scenarios leading to these incidents to inform current test methods and potential mitigating strategies. This paper presents preliminary findings from the Fire Protection Research Foundation project on "fire hazards of exterior wall assemblies containing combustible composites". At the time this paper was written this project is at a preliminary, information gathering stage.

\section{FIRE PROTECTION RESEARCH FOUNDATION PROJECT}

The Fire Protection Research Foundation has initiated a research project on "fire hazards of exterior wall assemblies containing combustible components". The project objective is to develop the technical basis for evaluation, testing and fire mitigation strategies for fire hazards of exterior wall systems with combustible components. This research project is split into two phases.

Phase 1 of the project includes review of available fire statistics, fire incidents, literature and test methods relating to combustible external wall assemblies including those assemblies listed below.

- Exterior Insulation Finish Systems (EIFS) or synthetic stucco

- Metal composite claddings such as Alucabond and Alpolic

- High-pressure laminates

- Structural Insulation Finish Systems (SIFS) and insulated sandwich panel systems

- Weather-resistive barriers (WRB).

- External timber panelling and facades including cross laminated timber (CLT).

This is an Open Access article distributed under the terms of the Creative Commons Attribution License 2.0, which permits unrestricted use, distribution, and reproduction in any medium, provided the original work is properly cited. 


\section{MATEC Web of Conferences}

The scope of the current effort, which is summarized in this paper, only covers Phase 1. A possible Phase 2 effort would include experiments to evaluate performance of exterior walls with combustible materials.

\section{U.S. FIRE STATISTICS 2007-2011}

\subsection{Methodology}

A preliminary statistical analysis of building fires reported to U.S. municipal fire departments has been completed for fire incidents relating to exterior walls.

The 2007-2011 statistics in this analysis are projections based on the detailed coded information collected in Version 5.0 of the U.S. Fire Administration's (USFA's) National Fire Incident Reporting System (NFIRS 5.0) and the findings of the National Fire Protection Association's (NFPA's) annual survey of local or municipal fire department experience $[1,2]$.

The number of NFIRS code choices relating to exterior wall fires is very limited and does not capture information such as the type of exterior wall material (combustible or non-combustible), the extent of fire spread, or the mechanism of fire spread (external surface or within cavity).

Except for property use and incident type, fires with unknown or unreported data were allocated proportionally in all calculations. Casualty and loss projections can be heavily influenced by the inclusion or exclusion of one or more unusually serious fires. Property damage has not been adjusted for inflation. Fires, civilian deaths and injuries are rounded to the nearest one and direct property damage is rounded to the nearest hundred thousand dollars (US).

Fires involving structures other than buildings (incident type 112), and fires in mobile property or portable buildings used as a fixed structure (incident type 120-123) were also excluded.

The following property type use codes were included:

- Public assembly (100-199)

- Educational (200-299)

- Health care, nursing homes, detention and correction (300-399)

- Residential, excluding unclassified (other residential) and one-or two-family homes (420-499). This includes hotels and motels, dormitories, residential board and care or assisted living, and rooming or boarding houses.

- Mercantile (500-589)

- Office buildings, including banks, veterinary or research offices, and post offices (590-599)

- Laboratories and data centres $(629,635$, and 639)

- Manufacturing or processing (700)

- Selected storage properties: Refrigerated warehouses, warehouses, other vehicle storage, general vehicle parking garages, and fire stations $(839,880,882,888$, and 891).

Fires involving structures other than buildings (incident type 112), and fires in mobile property or portable buildings used as a fixed structure (incident type 120-123) were also excluded.

Separate queries were performed for:

- Fires starting in or the exterior wall surface area (area of origin code76),

- Fires that did not start on the exterior wall area but the item first ignited was an exterior sidewall covering, surface or finish, including eaves, (item first ignited code 12); and for

- Fires which did not start in the exterior wall or area or with the ignition of exterior sidewall covering but fire spread beyond the object of origin (fire spread codes 2-5) and the item contributing most to fire spread was the exterior sidewall covering (item contributing to flame spread code 12).

Results were summed after unknown or missing data, including extent of fire spread for the last condition, were allocated. This summed result is taken to represent the total number of exterior wall fires. 
Table 1. Total structure fires in selected properties.

\begin{tabular}{|l|c|c|c|c|c|}
\hline Property use & Fires & $\begin{array}{c}\text { Civilian } \\
\text { deaths }\end{array}$ & $\begin{array}{c}\text { Civilian } \\
\text { injuries }\end{array}$ & $\begin{array}{c}\text { Property damage } \\
\text { (US\$ Millions) }\end{array}$ & $\begin{array}{c}\text { Portion of } \\
\text { total fires }\end{array}$ \\
\hline Public assembly & 15,374 & 6 & 172 & $\$ 446.2$ & $(9 \%)$ \\
\hline Educational & 6,012 & 0 & 90 & $\$ 105.1$ & $(3 \%)$ \\
\hline Institutional, & 7,153 & 6 & 182 & $\$ 59.6$ & $(4 \%)$ \\
\hline Residential & 121,651 & 485 & 4,592 & $\$ 1,548.8$ & $(68 \%)$ \\
\hline Mercantile & 15,198 & 20 & 287 & $\$ 724.8$ & $(9 \%)$ \\
\hline Office building & 3,538 & 4 & 40 & $\$ 112.1$ & $(2 \%)$ \\
\hline Laboratory \& Data centre & 234 & 0 & 10 & $\$ 22.5$ & $(0 \%)$ \\
\hline Manufacturing or processing & 5,742 & 8 & 176 & $\$ 593.2$ & $(3 \%)$ \\
\hline Selected storage occupancies, & 2,930 & 8 & 45 & $\$ 230.7$ & $(2 \%)$ \\
\hline Total & 177,833 & 537 & 5,595 & $\$ 3,842.9$ & $(100 \%)$ \\
\hline
\end{tabular}

Table 2. Exterior wall fires - Building fires in selected properties in which the area of origin, item first ignited or item contributing most to flame spread was an exterior wall.

\begin{tabular}{|l|c|c|c|c|c|}
\hline Property use & Fires & $\begin{array}{c}\text { Civilian } \\
\text { deaths }\end{array}$ & $\begin{array}{c}\text { Civilian } \\
\text { injuries }\end{array}$ & $\begin{array}{c}\text { Portion of } \\
\text { Property damage } \\
\text { (US\$Millions) }\end{array}$ & $\begin{array}{c}\text { total structure } \\
\text { fires }\end{array}$ \\
\hline Public assembly & 706 & 0 & 6 & $\$ 30.8$ & $(5 \%)$ \\
\hline Educational & 127 & 0 & 0 & $\$ 2.8$ & $(2 \%)$ \\
\hline Institutional, & 94 & 0 & 0 & $\$ 4.6$ & $(1 \%)$ \\
\hline Residential & 2,889 & 18 & 133 & $\$ 197.2$ & $(2 \%)$ \\
\hline Mercantile & 891 & 0 & 5 & $\$ 31.1$ & $(6 \%)$ \\
\hline Office building & 210 & 0 & 3 & $\$ 7.6$ & $(6 \%)$ \\
\hline Laboratory \& Data centre & 5 & 0 & 0 & $\$ 1.5$ & $(2 \%)$ \\
\hline Manufacturing or processing & 120 & 0 & 1 & $\$ 6.3$ & $(2 \%)$ \\
\hline Selected storage occupancies, & 303 & 0 & 0 & $\$ 13.1$ & $(10 \%)$ \\
\hline Total & 5,346 & 18 & 148 & $\$ 295.0$ & $(3 \%)$ \\
\hline
\end{tabular}

Separate queries were performed for four above ground height groupings:

- one to two stories,

- three to five stories,

- six to ten stories, and

- 11 to 100 stories.

Separate queries were performed for four categories of automatic extinguishing system (AES) presence:

- Present [code 1],

- Partial system present [code 2],

- NFPA adjustment indicating AES presence but the reason for failure was the AES was not in the fire area [converted to code 8], and

- None present [code N].

\subsection{Results}

Table 1 shows the total number of "structure fires" in the selected property types overall, regardless of the area of origin or item first ignited. This includes fires with confined fire incident types (incident type 113-118), including cooking fires confined to the vessel of origin, confined chimney or flue fires, 


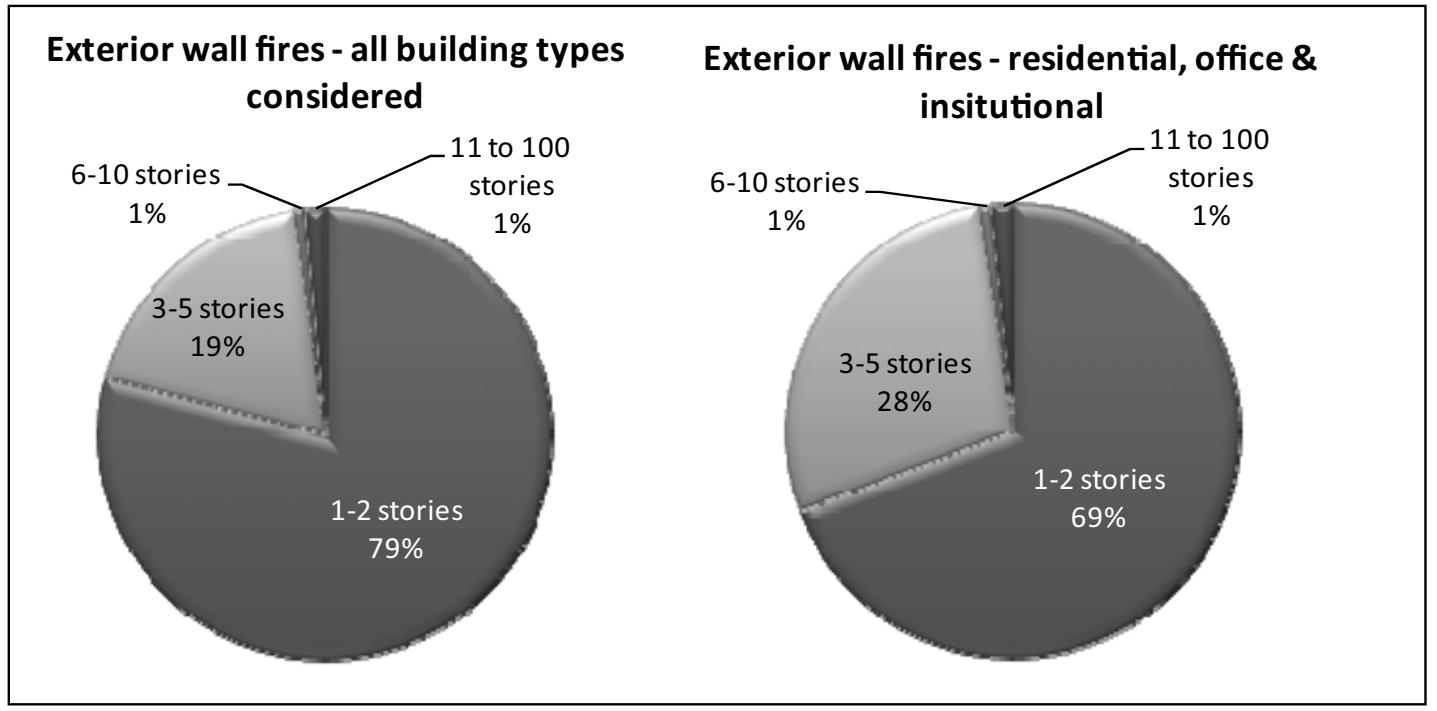

Figure 1. Percentage of Exterior wall fires by building height.

confined incinerator fires, confined compactor fires, confined fuel burner or boiler fires, and trash or rubbish fires inside a structure with no damage to the structure or its contents.

Table 2 shows the total shows the building fires in selected properties that began on, at or with an exterior wall, by property use. These exclude the confined fire incident types listed above.

For all building types, Exterior wall fires accounted for $3 \%$ of all structure fires. Exterior wall fires also accounted for $3 \%$ of civilian deaths and injuries and $8 \%$ of property damage. The highest number exterior wall fires occurred in residential buildings, and was $2 \%$ of the total residential structure fires. However, the percentage of residential structure exterior wall fires was lower than the percentage of selected storage properties, public assembly, office buildings, and mercantile properties, with exterior wall fires being $10 \%$ of storage occupancy structure fires.

For exterior wall fires in the selected occupancies

- $42 \%$ were fires starting on the exterior wall surface,

- $32 \%$ were fires where the area of origin was not exterior wall, but item first ignited was exterior sidewall covering, and

- $26 \%$ were fires where area of origin or item first ignited were not an exterior wall but the item contributing most to fire spread was an exterior wall.

Inclusion of the exterior wall as the area of origin or item first ignited may be capturing scenarios such as fires in external fuel loads located against external walls or exposure of external walls to fires from adjacent buildings where the fire spreads to the interior of the building but the external (combustible or non-combustible) wall does not play a significant role in the fire spread.

The percentage of exterior wall fires within buildings of different height categories is shown in Figure 1. This indicates that the vast majority of exterior wall fires occur within low rise (5 stories or less) buildings. This may be due to two reasons:

- The majority of the building stock is low rise.

- Sprinklers are more likely to be installed in high rise buildings and reduce the risk of internal fires spreading via openings to the external facade.

As a sensitivity study, the percentage of exterior fires by building height has been plotted for only residential, office and institutional type buildings as these are expected to have a larger proportion of 


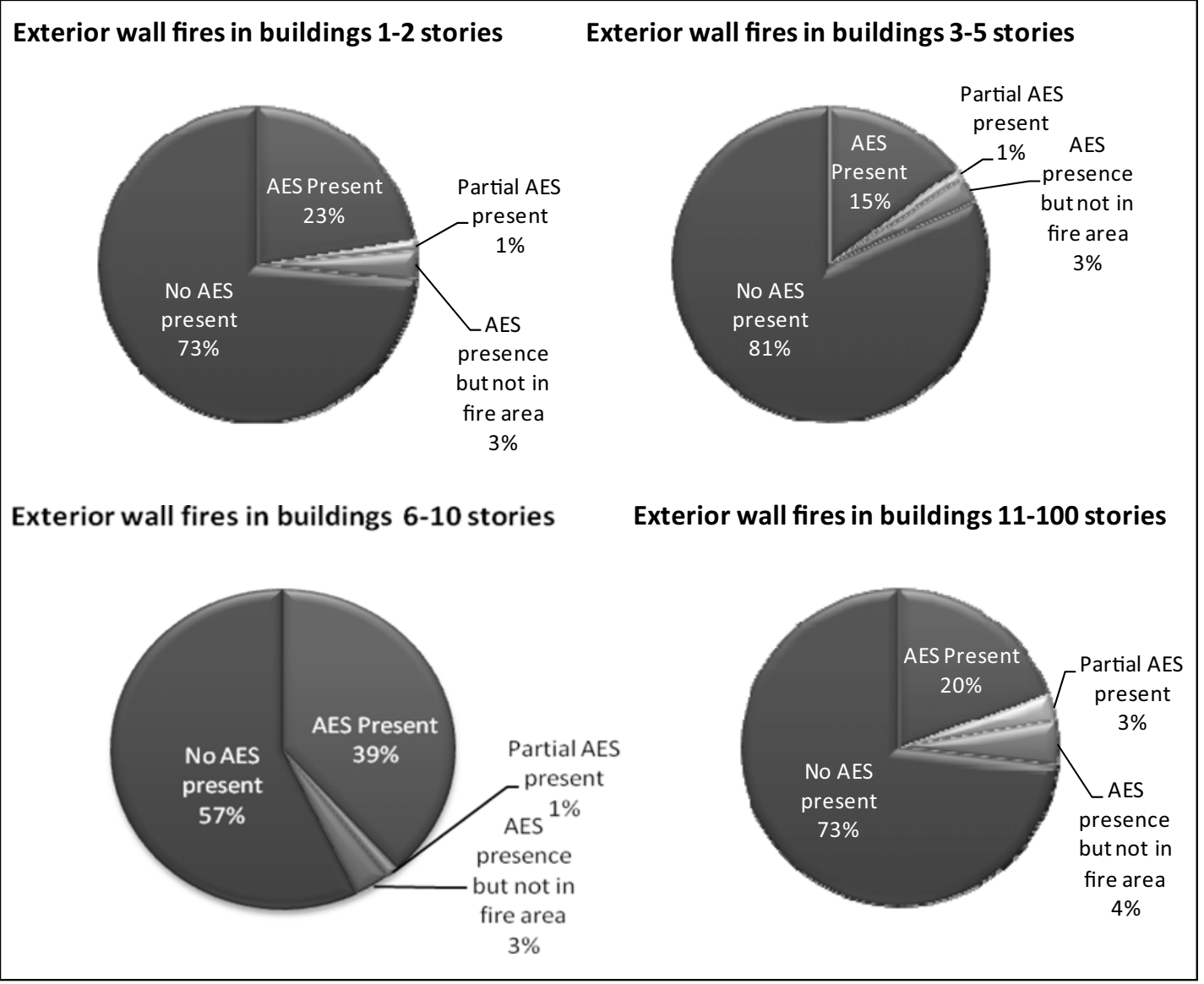

Figure 2. Percentage of exterior wall fires by presence of automatic extinguishing system.

high rise building stock compared with other building types such as storage, manufacturing, mercantile and educational. A slightly increased percentage of exterior wall fires occur in three to five stories buildings compared to the other building types.

Figure 2 shows the percentage of exterior wall fires by presence of automatic extinguishing system within the different building height categories. Figure 2 indicates that the majority of exterior wall fires occur in buildings with no automatic suppression system or no automatic suppression system installed in the fire area. Two points need to be considered when examining this data. The NFIRS data element "presence of automatic extinguishing system" is intended to document "the existence of an AES within the AES's designed range of a fire. NFPA added the category "present, but not in fire area, when an AES was coded as present, but the reason for a failure to operate was "Fire not in area protected."

Typical thresholds above which sprinkler systems are required in the International Building Code (IBC), 2012 Edition [3], include:

- Mercantile: Over 12,000 $\mathrm{ft}^{2}\left(1115 \mathrm{~m}^{2}\right)$ in one fire area, or over $24,000 \mathrm{ft}^{2}\left(2230 \mathrm{~m}^{2}\right)$ in combined fire area on all floors, or more than 3 stories in height

- High-Rise: All buildings over $55 \mathrm{ft}$ (16.8 m) in height

- Residential Apartments: All buildings except townhouses built as attached single-family dwellings. 


\section{MATEC Web of Conferences}

Table 3. NSWFB building fire statistics for area of fire origin [5].

\begin{tabular}{|l|l|l|l|l|}
\hline \multirow{2}{*}{ Area of fire origin } & \multicolumn{4}{|c|}{ Year } \\
\cline { 2 - 6 } & $2003 / 04$ & $2004 / 05$ & $2005 / 06$ & $2006 / 07$ \\
\hline $\begin{array}{l}\text { Wall assembly, } \\
\text { concealed wall space }\end{array}$ & 34 & 31 & 32 & 32 \\
\hline Exterior wall surface & 82 & 77 & 95 & 69 \\
\hline $\begin{array}{l}\text { Total building fires } \\
\text { (all areas of fire origin) }\end{array}$ & 6,388 & 6,165 & 6,566 & 6,257 \\
\hline
\end{tabular}
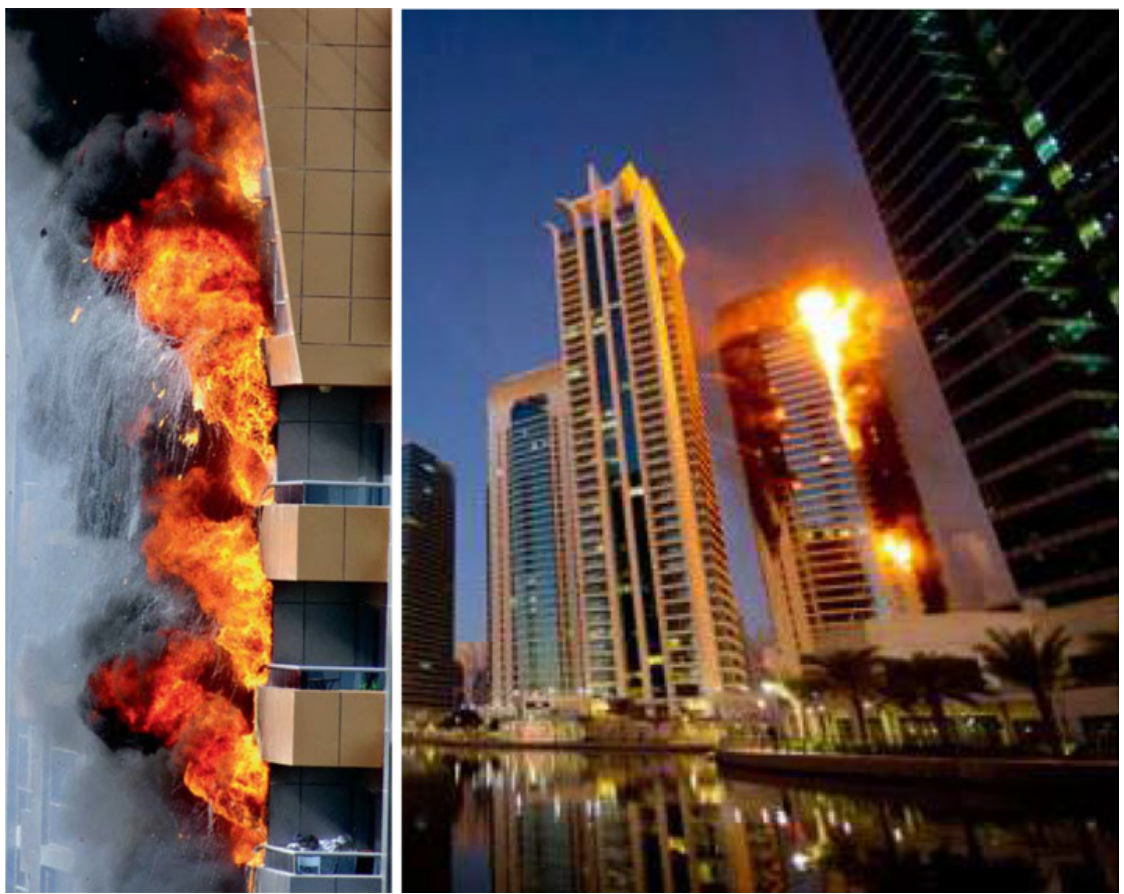

Figure 3. Saif Belhasa building fire, Tecom 2012 (left) \& Tamweel Tower fire 2012 (right).

Typical thresholds above which sprinkler systems are required in NFPA 5000, Building Construction and Safety Code, 2012 Edition [4] include:

- Mercantile: Over $12,000 \mathrm{ft}^{2}\left(1115 \mathrm{~m}^{2}\right)$ in gross fire area or three or more stories in height

- High-Rise: All buildings over $75 \mathrm{ft}(22.9 \mathrm{~m})$ in height

- Residential Apartments: All buildings except those in which each unit has individual exit discharge to the street.

Although it is expected that the majority of high-rise buildings (6 stories or more) would have at least internal sprinkler systems, the majority of exterior wall fires for high rise buildings occur in buildings where no suppression system is installed. It is concluded that sprinkler systems are likely to have a significant effect on the risk of exterior wall fires. For example internal sprinklers reduce the risk of spread from an internal fire to the exterior facade.

The data presented in Figure 2 provides no information regarding failure of automatic suppression systems where installed. However, previous NFPA reports address sprinkler effectiveness in general. The data also does not enable analysis of the effectiveness of internal sprinklers vs external facade sprinklers in preventing exterior wall fire spread. 

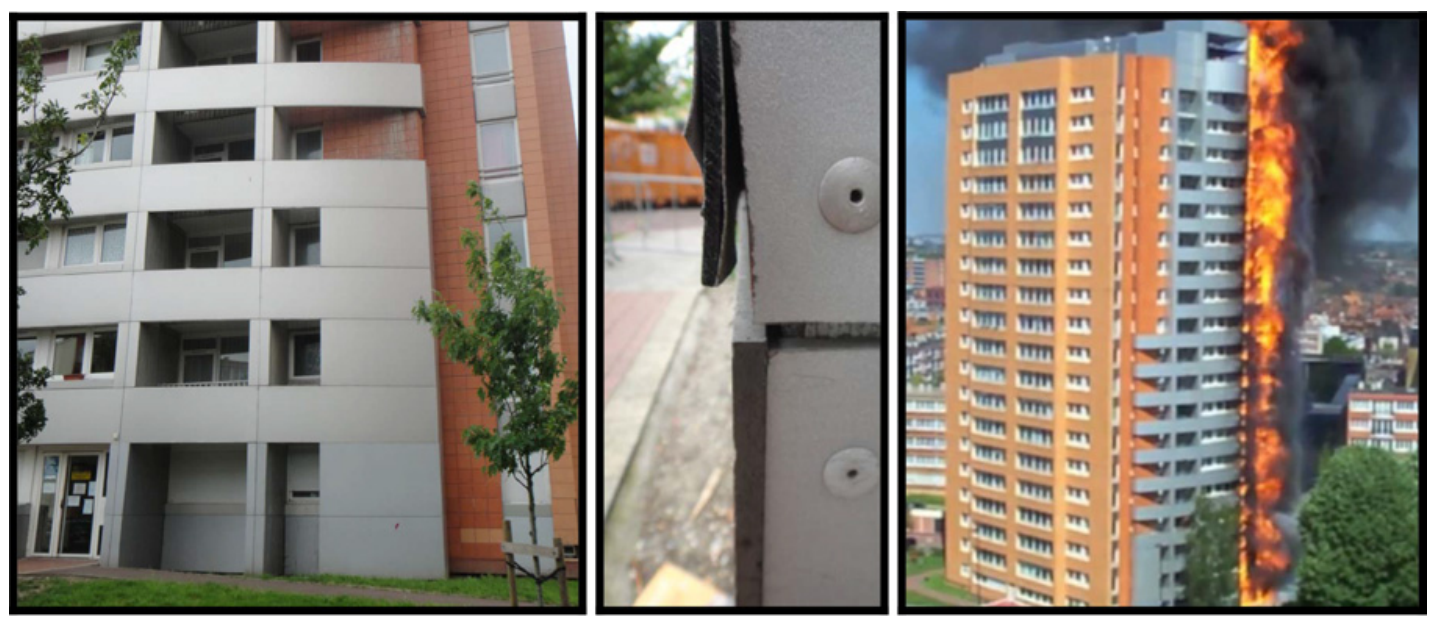

Figure 4. Mermoz Tower, Roubaix, France [13-16] May 2012.

\section{OTHER FIRE STATISTICS}

\subsection{New South Wales fire brigade statistics, Australia}

The Australian Incident Reporting System (AIRS) is an Australian national database framework for incidents reported to emergency services. Unfortunately not all Australian fire brigades actively report to AIRS and it is currently not well maintained or easy to retrieve data from.

New South Wales Fire Brigade (NSWFB) is one of the largest fire brigades in Australia. NSWFB publish annual fire statistics which represent a selection of the NSWFB AIRS data. The only information relating to exterior wall fires is the "area of fire origin" as shown in Table 3.

This indicates fires starting in wall assembly/concealed wall space are $0.5 \%$ of the total fires and fires starting on exterior wall surfaces are $1.3 \%$ of total fires. NSWFB statistics provide no information relating to the number of fires where the main area or fire spread was the exterior wall assembly or the types of exterior wall assemblies involved.

\subsection{New Zealand fire service emergency incident statistics}

The New Zealand Fire Service (NZFS) publish annual fire statistics in a similar format to NSWFB. Again, the only information relating to exterior wall fires is the "area of fire origin" as shown in table.

This indicates that fires starting in wall assembly/concealed wall space are $1.7 \%$ of the total fires and fires starting on exterior wall surfaces are $5.0 \%$ of total fires.

Fire statistics in the UK and Europe are currently being collected.

\section{SELECTED FIRE INCIDENTS}

Although the rate of fires resulting in extensive fire spread involving combustible exterior wall systems is low, the consequences of such fires is potentially very large. Examples of incidents on various different types of combustible wall systems from around the world are presented.

\subsection{Fires involving aluminium composite panels}

A spate of recent facade fires in the United Arab Emirates has involved aluminium composite panels with polyethylene cores. On 18 November 2012 a fire started at the top of the 34-storey Tamweel 


\section{MATEC Web of Conferences}

Table 4. NZFS building fire statistics for area of fire origin [6].

\begin{tabular}{|l|l|l|l|l|l|}
\hline \multirow{2}{*}{ Area of fire origin } & \multicolumn{5}{|c|}{ Year } \\
\cline { 2 - 6 } & $2009 / 10$ & $2008 / 09$ & $2007 / 08$ & $2006 / 07$ & $2005 / 06$ \\
\hline $\begin{array}{l}\text { Wall assembly, } \\
\text { concealed wall space }\end{array}$ & 72 & 111 & 121 & 99 & 98 \\
\hline Exterior wall surface & 224 & 321 & 355 & 307 & 290 \\
\hline $\begin{array}{l}\text { Total building fires } \\
\text { (all areas of fire origin) }\end{array}$ & 4,738 & 6,361 & 6,235 & 6,269 & 6,111 \\
\hline
\end{tabular}

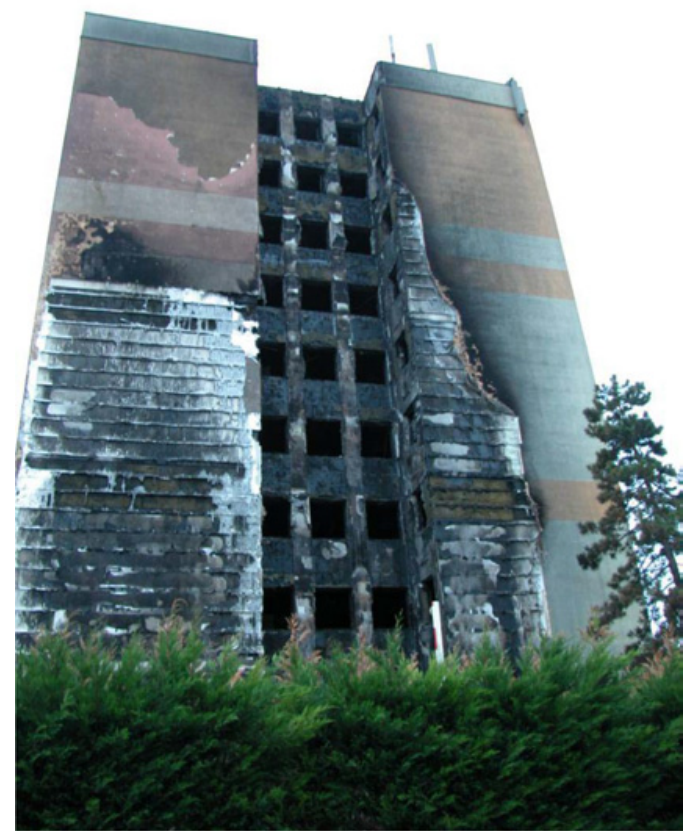

Figure 5. EIFS fire, Dijon, France on 14 November 2010.

Tower, Dubai resulting in rapid fire spread down the external facade to ground level [7, 8]. This was accompanied by a significant amount of falling flaming debris. In October 2012 a fire started in the fourth floor of the 13 storey residential building in Dubais's Tecom area [9, 10]. The fire rapidly spread upwards on the aluminium composite facade to all floors above. A similar fire occurred in April 2012 in a 14 storey residential building, Al Tayer Tower in Sharjah with the fire starting on the second floor and spreading to all floors via the aluminium composite facade [11].

A change to the UAE Building code has been drafted to address fire safety requirements for facades [12] however it is estimated that non-fire resistant aluminium composite panels are currently installed on around $70 \%$ of high rise building facades in the UAE.

A similar fire occurred on 14, May 2012 at the Mermoz Tower, Roubaix, France [13-16]. The fire started on a second storey balcony of the 18 storey residential building. Flames spread upwards on the facade reaching the top of the building and resulting in one fatality. Fire spread up through external balcony channel which was lined with $3 \mathrm{~mm}$ thick aluminium composite cladding. 


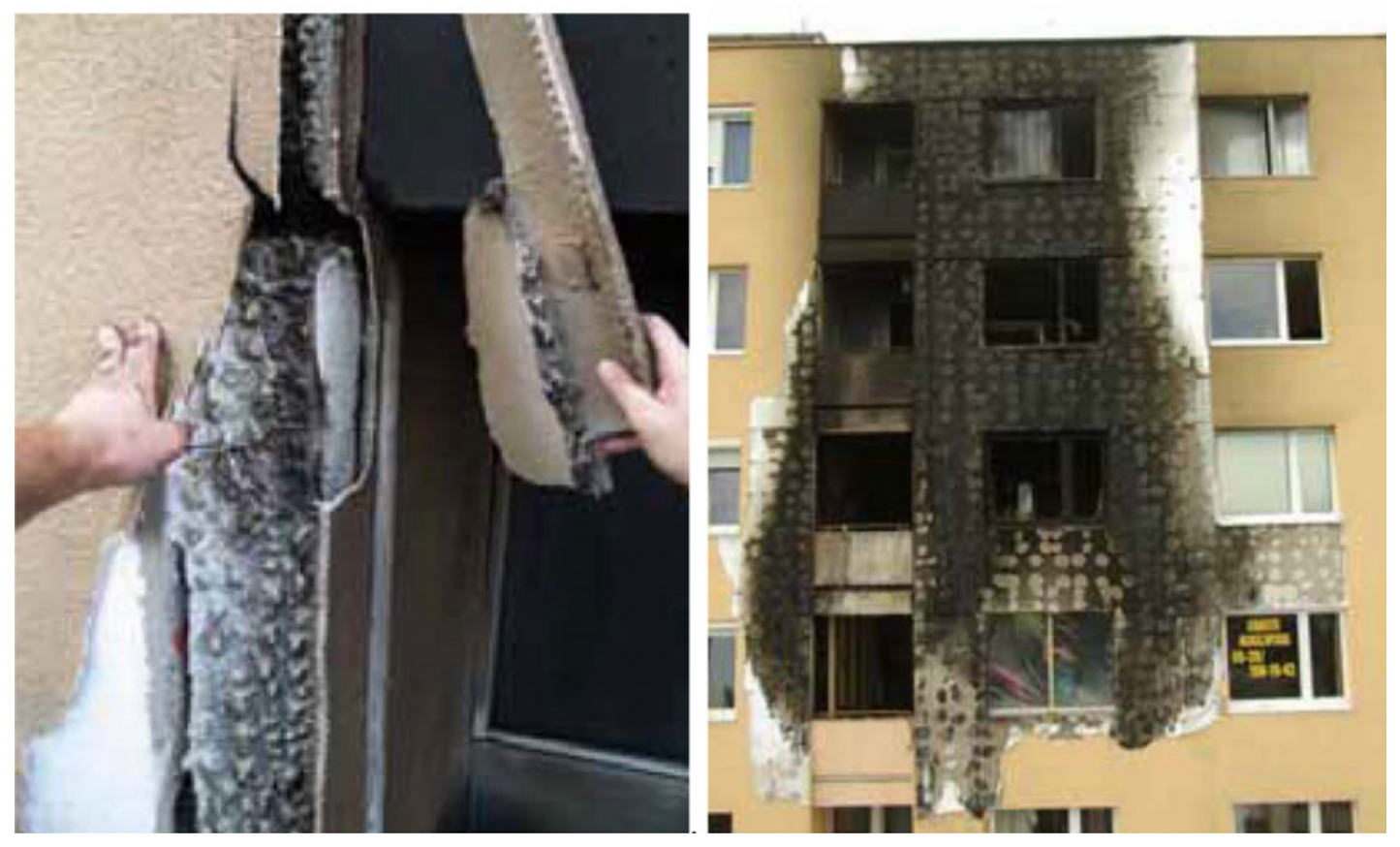

Figure 6. EIFS fire, Mikolc, Hungary, 15 August 2005, in.

\subsection{Fires involving EIFS}

A fire in a residential building in Dijon, France on 14 November 2010 resulted in 7 fatalities [17]. The fire started in an external garbage container resulting in rapid vertical fire spread on the façade. The façade was an EIFS system with EPS insulation and mineral wool fire barriers.

On 15 August 2005, in Mikolc, Hungary, a fire started in a $6^{\text {th }}$ floor residential kitchen resulting in vertical fire spread on the EIFS façade to the top of the 11 story building, resulting in 3 fatalities. Factors contributing to the fire spread were the use of EPS insulation, inadequate installation of insulation and protective render and no use of mineral wool fire propagation barriers, particularly around window reveals [18].

\subsection{Fires involving other combustible wall materials}

There has been some very large façade fire incidents reported in China. Unfortunately, detailed information on these incidents or any regulatory changes in China has not been available. One example is the Shanghai 28-storey residential building fire on 15 November 2010, believed to be caused by welding resulting fire spread on polyurethane insulation to external walls. This resulted in 58 fatalities [19]. Another example is the China Central Television headquarters (CCTV Tower). A 44 storey tower nearing completion of construction. The facade at the top of the building was ignited by illegal fireworks. The fire spread to involve the majority of the facade over the entire height of building. The façade is believed to have included a polystyrene insulation [20].

\section{TEST METHODS}

This project will examine and compare applicable tests for combustible exterior wall assemblies such as BS8414 part $1 \& 2$, ISO 13785 part $1 \&$ 2, NFPA 285, SP105, CAN/ULCS134, DIN 4102-20 and the 

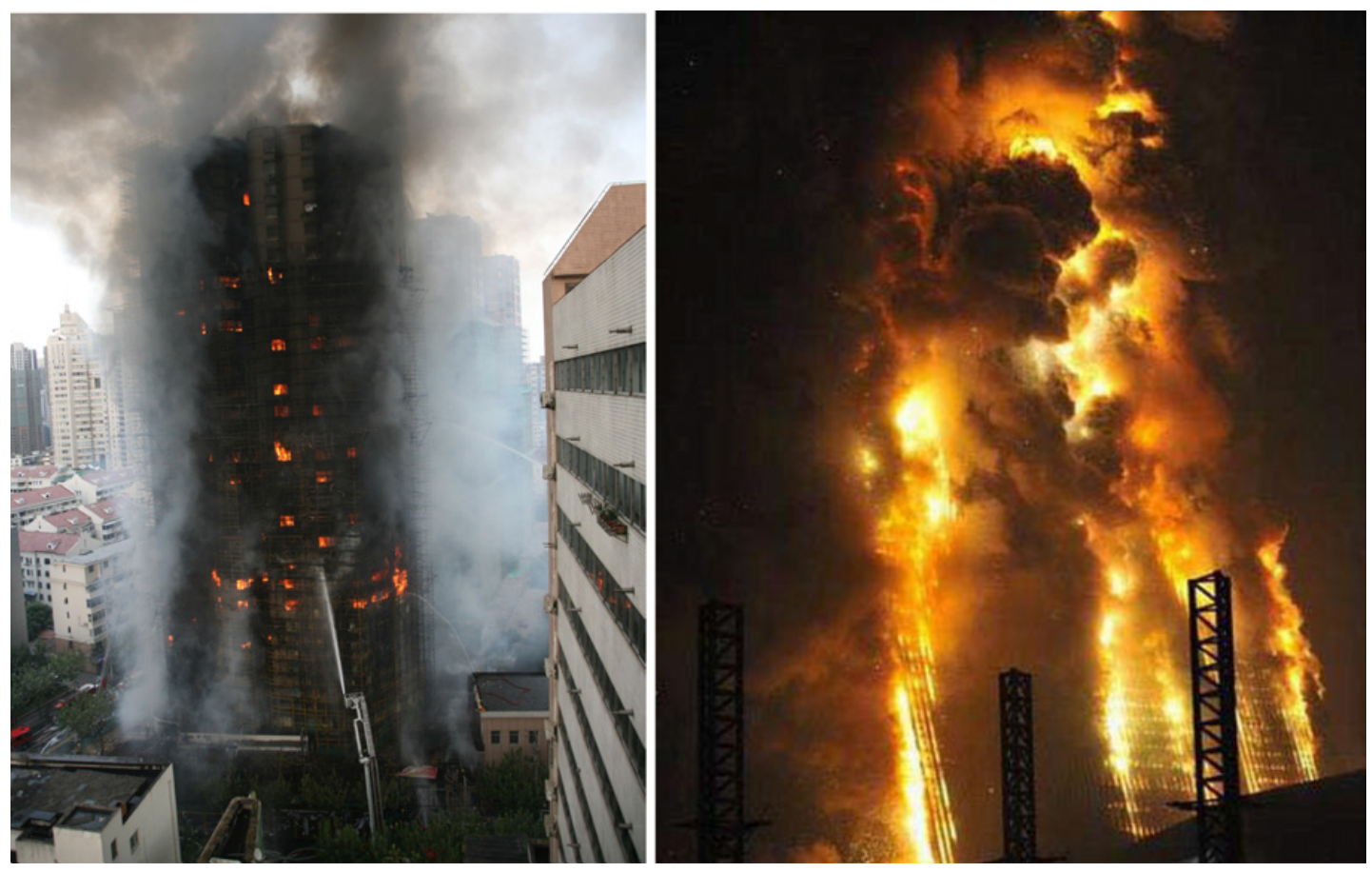

Figure 7. Shanghai Fire (left) and CCTV Tower, Beijing fire (right).

BRANZ Vertical channel test. It will also examine small scale fire tests which may be used for screening of materials or determination of key flammability properties of the individual elements of the facades that could be used for modeling.

The purpose of this review is to ascertain the degree to which these tests are uniform or equivalent throughout the world as well as whether the tests and standards are adequate for control of fire hazards for combustible exterior wall assemblies, particularly in high-rise buildings.

Based on a preliminary review:

- Dimensions and physical arrangement of facade tests vary. As an example, some large-scale tests involve external corner walls 8 meters high (UK) or $5.7 \mathrm{~m}$ high (Germany and ISO) and $2.4 \mathrm{~m}$ and $1.3 \mathrm{~m}$ wide

- There are wide differences in the source fire simulating a fire in the room of origin. Wood cribs, liquid pool fires and gas burners are being used to generate maximum heat fluxes on the façade in the range of 20 to $90 \mathrm{~kW} / \mathrm{m} 2$. It will be investigated if these fires represent a sufficient exposure for real life situations.

- Test durations, measurements and acceptance criteria vary.

- The degree to which suitability of fixing systems and fire spread through joints, voids and window assemblies of a multifunctional façade assembly are tested varies. The Swedish SP-105 test appears to address this by including multiple window openings in the tested façade.

- Whilst large-scale facade tests do not measure key flammability properties of the individual elements of the facades for direct input to modelling. These tests do provide useful validation for fire spread modeling.

We believe that the existing standards are good to some extent. However, based on this review it is possible that improvements to the current test methods may be identified to better cover the multitude 
of façade material systems and wide range of fire scenarios, such as large flash-over fires with excess pyrolysate burning outside the room of the original fire.

\section{CONCLUSIONS}

This paper presents preliminary findings from the Fire Protection Research Foundation project on 'fire hazards of exterior wall assemblies containing combustible composites'. At the time this paper was written this project is at a preliminary, information gathering stage.

A review of statistics indicates the following:

- Exterior wall fires appear to account for somewhere between $1.3 \%$ and $3 \%$ of total building fires.

- The statistics reviewed do not provide detail relating to the types of combustible wall systems involved and the extent of fire spread.

- The US NFIRS is one of the best maintained fire incident databases worldwide. It is expected that more detailed statistics relating to combustible exterior wall assembly fires are unlikely to be available.

Some examples of significant combustible façade fires have been presented. This indicates that whilst the rate of these fires is relatively low, the consequences in terms of property damage and fatalities can be large.

The fire incidents presented are generally considered to be examples where materials or installation methods have been used which would not be expected to meet regulations and test criteria in countries where control of combustible facades is well developed.

The project objective is to develop the technical basis for evaluation, testing and fire mitigation strategies for exterior fires exposing exterior wall systems with combustible components. This will be achieved by further review of fire incidents and statistics, and regulations and test methods currently adopted around the world.

NFPA's Fire Analysis Division has been of great assistance to conduct the review of the National Fire Incident Reporting System database.

\section{References}

[1] John R. Hall Jr. BH. (1989) The national estimates approach to U.S. fire statistics. Fire Technology. 1989 May 1989; Volume 25(Issue 2):pp 99-113.

[2] (2010) National Fire Incident Reporting System - complete reference guide. July 2010.

[3] ICC. (2012) 2012 International Building Code USA.

[4] (2012) NFPA 5000, Building Construction and Safety Code. Quincy, MA

[5] (2003-2007) NSW Fire Brigades Annual Statistical Reports 2007-2007. Sydney, NSW, Australia.

[6] (2005-2010) The New Zealand Fire Service Emergency Incident Statistics 2005-2010. Wellington, New Zealand.

[7] Croucher M. (2012) Residents of Dubai's Tamweel Tower relive fire ordeal. TheNationalUAE. 2012 Nov 19, 2012

[8] Croucher M. (2012) Aggressive changes to UAE fire-safety code after hundreds left homeless. TheNationalUAE. 2012 Nov 26, 2012

[9] (2012) Two Serious Fire Outbreaks in Dubai Towers. FIRE Middle East. 2012.

[10] Barakat JPdLaN. (2012) Fire in Tecom building leaves seven families homeless. Gulf News. 2012 October 6, 2012.

[11] Derek Baldwin JPdL. (2012) Tower cladding in UAE fuels fire. Gulf News. 2012 May 2, 2012. 


\section{MATEC Web of Conferences}

[12] (2013) UAE Fire \& Life Safety Code of Practice - Annexure A.1.21. Fire Stopping, Exterior Wall Cladding and Roofing Systems (DRAFT). United Arab Emirates.

[13] Messerschmidt B. (2012) RE: Another Exterior Wall Fire. Received by: White N. Email containing power point slides of Rockwool investigation of facade fire in Roubaix, France 14th May 2012. Received: Thu 11/07/2013 11:27 PM.

[14] (2013) l'incendie tour mermoz pompiers de Roubaix [Movie]. YouTube; 2013 [cited 201319 July 2013]. Footage of Mermoz Tower Fire, Roubaix, France]. Available from: http://www.youtube.com/watch?v=j4mIBQnUAfQ.

[15] (2012) Spectacular High-Rise Fire in France 2012 [cited 201319 July 2013]. Blog report on Mermoz Tower fire, Roubaix, France]. Available from: http://firegeezer.com/2012/05/15/ spectacular-high-rise-fire-in-france/.

[16] (2012) High-rise blaze in 18-storey block in Roubaix, France 2012 [cited 201319 July 2013]. Blog report on Mermoz Tower fire, Roubaix]. Available from: http://www.blog.plumis.co.uk/ 2012/05/ high-rise-blaze-in-18-storey-block-in.html.

[17] (2010) Seven die in fire in immigrant hostel in Dijon, France. BBC News Europe. 201014 November 2010

[18] HAJPÁL DM, editor (2012) Analysis of a tragic fire case in panel building of Miskolc. Integrated Fire Engineering and Response; 2012; Malta.

[19] (2013) 2010 Shanghai fire Wikipedia2013 [cited 201322 July 2013]. Available from: http://en.wikipedia.org/wiki/2010_Shanghai_fire\#cite_note-8.

[20] (2013) Beijing Television Cultural Center fire: Wikipedia; 2013 [cited 201320 July 2013]. Available from: http://en.wikipedia.org/wiki/Beijing_Television_Cultural_Center_fire. 